\title{
Perceptual Errors in Late Medieval Philosophy
}

\section{Silva, José Filipe}

Routledge

2019

Silva , J F \& Toivanen , J 2019 , Perceptual Errors in Late Medieval Philosophy . in B Glenney \& J F Silva (eds), The Senses and the History of Philosophy . Rewriting the History of Philosophy , Routledge , London and New York , pp. 106-130 . https://doi.org/10.4324/9781315184418-10

http://hdl.handle.net/10138/317455

https://doi.org/10.4324/9781315184418-10

unspecified

acceptedVersion

Downloaded from Helda, University of Helsinki institutional repository.

This is an electronic reprint of the original article.

This reprint may differ from the original in pagination and typographic detail.

Please cite the original version. 


\title{
Perceptual Errors in Late Medieval Philosophy
}

\author{
José Filipe Silva and Juhana Toivanen ${ }^{1}$
}

\section{Introduction}

In recent decades, scholars working in the field of philosophy have seen an increase in focus on theories of cognition, with perception receiving a fair share of this spotlight. This is to a large extent also true with respect to scholarship on medieval philosophy. For the most part, however, the focus has been on veridical perception, that is, perception that occurs under normal conditions and provides cognition of things as they are in the extra-mental world. ${ }^{2}$ Our focus in this paper is on those perceptual situations when things go wrong-on episodes of non-veridical perception in which things are perceived differently than they really are.

According to a very general picture, there are three requirements for veridical perception to take place: (1) the existence of a perceiving subject endowed with appropriate capacities or powers, including (a) the external senses, that is to say, the sense modalities of sight, touch, hearing, taste, and smell, which are associated with the respective sense organs, and (b) powers that are responsible for processing the information further, which medieval authors called the internal senses; (2) the existence of an object about which (and from which) information is made available to a perceiver; ${ }^{3}$ and (3) the sense organs and the medium, which mediates the object and the perceiver (air or water in the case of distal senses of vision, hearing, and smell), that are in proper or standard conditions. If these requirements are met, then the reception of sensory information leads to a perceptual experience, which makes the rational or non-rational perceiver aware of a particular external object or the perceptual property of such an object. It is important to note that 
these requirements are sufficiently general so as to remain largely uncommitted to any particular theory, but they are certainly characterized by having a realist and causal undertone.

Realism here means that, according to this general framework, perception pertains to perceptual properties as they exist in extra-mental objects, and their existence is independent of the perceiving subject. Were this not the case, all perceptions would be misperceptions, as Socrates remarks to the puzzled Theaetetus (Theaetetus 157e-158a), taking aim at the Protagorean theory of perception according to which all there is, is change. The causal undertone of the framework, on the other hand, means that perception requires a change caused from the outside by something (a thing or individual substance), which is already in actuality (e.g., colored) what the affected power is in potentiality to become and cognize (e.g., seeing color). ${ }^{4}$ This befits the original definition of perception found in Aristotle's De anima: "Sensation depends, as we have said, on a process of movement or affection from without, for it is held to be some sort of change of quality. ${ }^{5} \mathrm{~A}$ subject endowed with specific cognitive abilities becomes aware of certain objective features or properties of things as the result of the causal action of those properties with respect to such cognitive abilities. ${ }^{6}$

Given that this framework builds on causal explanations and adheres to realist presuppositions, perceptual errors are an anomaly that require special explanation. According to Aristotle:

Perception of the special objects of sense is never in error [...] for while the perception that there is white before us cannot be false, the perception that what is white is this or that may be false. ${ }^{7}$

Aristotle intends to present a simple contrast between (1) the perception of so-called proper sensibles of individual senses (color, sound, etc.), which cannot go wrong, and (2) 
more complex forms of perception that involve either common sensibles (size, number, etc.) or incidental sensibles, which are often mistaken. To say that the perception of proper sensibles can never err is, however, a gross simplification of Aristotle's view, as he himself recognizes by adding that there can be error, but only "to the least possible degree." ${ }^{8} \mathrm{He}$ seemingly provided this qualification to say that sense modalities get things right when the conditions in the medium (in the case of vision, air, or water) are optimal. Whenever these conditions are not realized, there either is no perception at all or else the object is perceived to be other than it is in reality, that is, as having a property that it does not have.

The details of the process in which the information from the object reaches the perceiver vary according to different theories. However, before the fourteenth century most medieval philosophers accepted, mostly without further ado, the basic realistic assumption that the senses are reliable. ${ }^{9}$ Skepticism was not considered a serious threat because perceptual errors were considered an anomaly in the general realistic framework. However, despite their optimism, medieval authors were ready to admit that perceptual errors do take place. The concern with perceptual errors was not so much with the consequences of occasionally failing to perceive things correctly; rather, the worry was about their elusiveness: Can we know their source and their occurrence so that we will know under what conditions these errors occur? Otherwise, if we are uncertain of the conditions for their occurrence, it is impossible to guarantee in a normative fashion that a given episode is an episode of veridical versus non-veridical perception. The threat then is that all perceptual experiences could be instances of non-veridical perceptions. By the end of the fourteenth century, as we will briefly show, that worry had taken root in the epistemological discourse, leading certain authors to develop strategies to ward off such worries. 
We proceed in this article by considering two general explanations for perceptual errors. The first consists, as noted before, of those cases where the conditions of the media through which the information is made available to the perceiver are not optimal. We also include problems related to the organs of the external senses in this category, which we call "transmission errors"; they cover everything that may affect the process of transmitting information from objects to perceivers. The second explanation for perceptual errors appeals to the further processing of this information. We call these "errors of judgment," since they result from failures of the complex cognitive apparatus, which occasionally does not operate properly when combining and interpreting the raw data that is received via the senses.

It might be argued that this distinction is problematic because a certain kind of judgment is already made at the level of the external senses-for instance, when vision discriminates (krinein) between black and white. This is even more pressing because medieval authors did not usually make a terminological distinction between this judgment and the more complex cases in which a judgment is made in relation to objects of more than one specific group of perceptual qualities - both are called judging/discriminating or making a judgment (iudicare, iudicium). This raises the question of whether these two kinds of judgments were considered to be fundamentally similar to each other, in which case the external senses, as cognitive powers, could in principle be included on the judgment-side of our division. ${ }^{10}$ However, the judgment/discrimination that takes place in the external senses does not have a compositional structure and cannot, therefore, be true or false strictly speaking. ${ }^{11}$ External senses may err, but not in the same way as the higher cognitive capacities do, due to their ability to make judgments in the more refined sense. 
We discuss the issues concerning transmission errors in section two and errors of judgment in section three. Both sections proceed by investigating authors representative of the "philosophical model" of Aristotelianism and its critics, as well as representatives of the "geometrical model" of perspectivist optics. The importance of this model becomes clear if one recalls that the early modern demise of the metaphysical theory underlying the Aristotelian theory of perception meant the collapse of the species doctrine (see below), but the perspectivist account survived and developed in Renaissance and early modern theories of vision and in less specialized cultural communities. ${ }^{12}$

\section{Roger That: Transmission Errors}

Perception can take place only if information from the object reaches the external senses.

The connection between the power and the object calls for an explanation, especially in the case of distal senses, like sight, hearing, and smell, which are not in direct contact with their objects. The traditional way to account for how the information is transmitted and received is described by William of Ockham (1285-1347) as follows:

[N]othing acts on a distant [thing] without acting first on the medium; but the distant perceptual [thing] acts on the sense; therefore, it first acts on the medium. That which is caused in the medium is the species, therefore etc. The minor premise is clear on the basis of Aristotle and Augustine, who say that the perceptual thing acts on the sense. ${ }^{13}$

As is well known, Ockham accepts action via distance in the case of perception, and therefore he is critical of this view. ${ }^{14}$ However, his description is accurate: most medieval authors thought that sensory information issues from the object in the form of a species (Latin: species). This technical term was used in an epistemological sense to account for the transmission of information from the object to the perceiver. ${ }^{15}$ It was understood (1) to be a representation or likeness of the object, a part of the object (e.g., its surface), or a property 
of the object (e.g., its color); (2) to issue forth from the object in order to make it known; and, (3) to cause a change in the medium and in the perceiver's senses. These aspects are true for all cases in which authors subscribe to this doctrine, irrespective of what each of them takes the species to represent, the ontological status of the species in the medium, the kind of change taking place in the medium and the sense organ, and whether or not the species is taken as the primary object of perception. ${ }^{16}$

Sensible species are efficient causes that actualize the potency of a sense power. Most medieval authors thought that the change the species causes is not material. An eye does not actually turn red when it is informed by a species of redness. ${ }^{17}$ Rather, medieval authors (or at least many of them) appealed to a distinction between material and spiritual change, or material and intentional being. The species of color, for instance, has an intentional mode of being in the medium and in the sense organ; it does not make them colored but instead transmits information in an "intentional" way. Thomas Aquinas argued on the basis of this distinction that the five external senses form a scale. The sense of touch is the most material of the senses, because it undergoes both material and spiritual change-when one touches a hot stove, one perceives hotness but, at the same time, one's finger becomes actually hot. At the other end of the scale is the sense of sight, which only undergoes spiritual change. All other senses fall in between these two.

\section{Transmission errors in the Aristotelian/Avicennian tradition}

Perception can yield reliable information about our environment only when it takes place under normal conditions: the medium must not be blocked or affected by anything, the lighting must be good, the sense organs must be healthy, and so forth. Since the process of perception involves a causal relation between the object and the perceiver, we are including 
under the heading of "transmission errors" all problems that affect the way the information is issued from the object and is received by the perceiver-up to and including the point in the process where the information enters the cognitive apparatus. In other words, the external senses, their organs, and their functions are included in the transmission problems. For instance, when a colored thing sends out a visible species, when the lighting conditions are right, when the medium is clear, a cataract may still prevent the information from reaching the perceiving subject correctly.

Given the fact that the objects of perception send forth a sensible species by nature (that is, automatically), the starting point of the process of transmission usually does not involve any problems. In contrast, the medium often causes different kinds of errors. Some perceptual qualities do not have a completely spiritual or intentional mode of being and are transmitted from the object to the sense organs via a material carrier-smells and sounds especially are liable to be affected by the medium, and then they reach the perceiver in an incomplete way. For instance, a strong wind confuses odors completely and distorts sounds in such a way that they cannot be perceived perfectly. ${ }^{18}$ Wind and other material causes cannot affect a visible species due to their spiritual/intentional mode of being in the medium, but even they can become confused if the light is dim, or if the air is not clear. Thus, for example, when sun shines through fog, it appears red and less bright than it really is, and things seen through a stained glass window appear to be tainted by the colors of the glass. ${ }^{19}$

Further, an error may arise due to the state of the sense organs. Aristotle mentions that a sick person may find that honey tastes bitter, and Aquinas explains this by appealing to a change in the organ: " $[\mathrm{A}]$ nd similarly everything appears bitter to those who are in pain - that is, to those who have fever-because they perceive [tastes] with a tongue that is 
full of this kind of moisture, namely bitter bile." ${ }^{20}$ Although honey remains sweet, a feverish person makes a cognitive error and perceives a bitter taste because of a change in the tongue. ${ }^{21}$

The state of the perceiving subject also affects more sophisticated contents of perception. Singular sounds and especially harmonies of several sounds may appear pleasing or harsh, depending on the overall state of the perceiver. John Blund (ca. 11851248) explains:

Inasmuch as one and the same sound appears to be harmonious to one hearer and harsh to another, it is not because of the nature of the sound itself, but rather because of the diversity of dispositions in the hearers. [...] If, however, the hearer is in good health, of the right constitution, and having the right proportion and balance of humours, the sound will seem to him to be harmonious, and it will be pleasing to him because of the correspondence of the sound to a balance with the disposition of the hearer. And that very same sound existing in the same quality will be disharmonious to the unhealthy man. ${ }^{22}$

Harmony of sounds is not a matter of subjective taste, since the mathematical ratio between two sounds is an objective feature. ${ }^{23}$ Nevertheless, the state of the perceiver influences how the harmony is perceived: a healthy person perceives it as fitting into her own harmonious state, while an unhealthy person apprehends the sounds as being disharmonious. The same combination of sounds that causes pleasure in a healthy person can be perceived as painful by one whose bodily disposition is affected by illness. A similar view was defended in the case of the other senses too. Peter Olivi (c. 1248-98) argues that whenever someone suffers or feels pleasure while perceiving an external thing, the contents of the cognitive operation remain the same. The difference between individual perceivers, or different species, is due to non-cognitive powers that are united with the external senses. Thus, although a bovine animal enjoys the taste of husk and humans find it rather bland, the members of these two species perceive exactly the same flavor, but only the former have an 
additional act of enjoyment in relation to it. Since this phenomenon also explains why a sick person does not like the sweet taste of honey, Olivi in fact rejects the idea that sickness causes misperception. ${ }^{24}$

Olivi's theory is an exception, however. Most medieval authors accepted the idea that the suffering caused by sickness is due to a cognitive error. More generally, they thought that the state of the organ is crucial in determining how things appear to us. A simple philosophical experiment can be used to show that this occurs in a vision. Pressing the eyeball has the effect of causing the objects in our field of vision to appear as two:

For, if a finger is pressed below the eye so that the position of the eye is changed, one thing is seen as two [...]. If we then suppose that it [scil. the reason] is held back so that it does not contradict that which appears, then it proclaims that one is two in reality, and it is deceived. If it is not held back but judges that to be nothing but an image in the sense, and not an existing thing, then it is not deceived, because that which appears in sensation does not seem to be true to it according to reason. ${ }^{25}$

The experiment shows how the state of the organ affects the way the visible species are received by it. Putting the organ in an abnormal state causes a misperception, and the perceptual content does not represent the external thing in a veridical manner, a case of overlap between transmission errors and errors of judgment. Even though the perceptual content is determined by external factors and the state of the perceiver, awareness of these conditions makes room for correcting the mistake. If the perceiver notices that her finger is pressing on her eyeball, she does not form an erroneous perceptual belief concerning the object. Judgment is based on the perceptual content without always being identical to it, and in cases like the one mentioned by Albertus, the perceptual content remains unaffected by ("encapsulated from") the judgment. Even when the subject becomes aware that she is seeing one thing as two, the duplicate does not disappear. 
The aforementioned transmission errors are based on the realist principle (to which we made reference early on) that unless there is something wrong in the medium or in the senses themselves, external things are perceived as they really are and believed to be so. This principle was also challenged in medieval discussion, as we shall see below, but we may note already here one startling idea that apparently calls it into question. When John Buridan (1295-1358) discusses the possibility of perceiving several things simultaneously (in relation to Aristotle's De sensu 7), he argues that this is indeed possible, but not everything is perceived equally well. He raises a possible objection to this view: when a white object is seen simultaneously with a black object that is beside it, the white color of the first object is seen more clearly in comparison to when it is seen alone. Buridan gives an answer, which may not be conclusive, but which is nevertheless possible:

[...] if one thing appears whiter and the other blacker, it does not follow that one of them is perceived more perfectly, because perhaps this [thing] appears whiter than it is, and that [thing] blacker than it is; and in this case one would be deceived and not perceiving perfectly. ${ }^{26}$

This idea seems to go against the realist assumption that things are perceived as they are unless there is something wrong in the conditions or in the perceptual process. In this scenario, there is nothing wrong with the medium or the sense of sight, and yet the white object is perceived differently than it is in reality. It is significant that Buridan is talking about the perception of a proper sensible, because in the case of common sensibles (such as size) this kind of error easily takes place. For instance, if one sees a distant object without realizing that it is far away, the object seems smaller than it is. However, in the case of proper sensibles this should not be possible. Buridan's suggestion entails that the relation between an object of perception and its surroundings affects the way it is perceived, but it is not easy to locate the source of error anywhere in this scenario. ${ }^{27}$ 


\section{Perspectivist tradition}

No clear distinction can be made between medieval Aristotelians and the so-called perspectivist authors, in the sense that both groups take the intromission of sensory information as the background model for their theories of perception. If anything, the difference between their starting points is a matter of focus: whereas Aristotelians were more interested in the psychological aspects of the process, perspectivists emphasized the nature of the transmission of the sensory information and the interconnection between low- and high-level cognitive powers. ${ }^{28}$ The focus of perspectivists is on visual perception, which they explain on the basis of visual rays flowing geometrically from every point of an object in all directions. Although there are differences between them, they shared key theoretical assumptions and even explanatory strategies. Our focus in this article will be on Ibn-Haytham, known in the Latin West as Alhacen (or Alhazen, 965-1040). ${ }^{29}$

In the third book of his De aspectibus, Alhacen presents a systematic and comprehensive investigation of all the conditions that lead to perceptual failure. He also takes pride in proving his interpretation of visual perception and perceptual errors by means of reason (ratione) and experimental evidence (experientia).$^{30}$ One important element in the perspectivist account is that occasional errors in the perceptual process do not affect the general reliability of perception; they require only that the theory provides a series of safeguards to validate the result of the experience. So, in order to understand how this model explains errors, we first need to give a brief account of how it gets things right. Second, we will need to establish a distinction between the information that is immediately made available to the perceiving subject and the content of the perceptual experience itself, which on occasion appeals to prior knowledge. Insofar as the two are not fully coincidental, 
they constitute a source of misperception. The principle is that, with respect to the three kinds of perception postulated by Alhacen, namely simple perception, perception by means of judgment, and perception by means of reasoning, ${ }^{31}$ there are three corresponding kinds of perceptual errors. Our task in the current section is to elaborate on these errors.

According to the model of perspectivist optics, visual perception requires that a number of conditions be met so that the information from the object of perception can be transmitted to the perceiver in a way that enables veridical perception. The eight conditions for visual perception are as follows: (1) distance (between object and perceiver), (2) light, (3) transparency (in the medium), (4) opacity (in the object), (5) magnitude (of the object), (6) and time, (7) as well as the fact that the object needs to directly face the eye, that is to say, it must be properly oriented towards the perceiver, and (8) the eye must be healthy. ${ }^{32}$ As can be seen, some of these conditions concern the perceiver, while others concern the object and still others the medium between them. Fulfilling all of these conditions means success in perceiving the object as it is (secundum quod est), whereas failing in any one of these conditions means misperception. ${ }^{33}$

The first problem to be considered is the case of double vision, which takes place when the visual fields of the two eyes do not completely overlap. An introductory explanation is here needed: according to the basic model of perspectivist optics, the field of vision of each eye is defined by imagining a cone extending from the center of the eye (the vertex), the base of which is the surface of the visible object. By means of the lines radiating from different parts of the surface, the arrangement of those parts is transmitted to the eye and perceived by the perceptual power (the ultimum sentiens) in accordance with their disposition at the surface of the object. The more an object stands at the intersection of the two visual axes, the more clear and distinct our visual perception of it is. ${ }^{34}$ The visual cone 
can be moved by moving the eyes, and this allows the perceiver to scan completely the object directly facing the perceiver. Under normal circumstances there are two visual fields, corresponding to the two eyes, which must match so that they provide the same image of the visible object facing the perceiver.

Alhacen's first solution to the problem of double vision is that the difference between the two points in the object, which are the vertex of the two visual cones, is minimal for objects of a moderate size and at a moderate distance, and therefore, the incoming information does not vary significantly ("it will be in nearly perfect correspondence"). ${ }^{35}$ Since there is no significant difference in the overlapping of the two visual cones, the form of the object that is produced in the common nerve-where the visual rays entering the two eyes converge-also shows this same level of agreement. ${ }^{36}$ Thus, the two rays entering the two eyes result in one form and the object is perceived as (being) one. If, however, the object is too close, the center of the object and its surrounding parts will be represented as one, because the visual axes intersect at the same point and determinate; but the extremities of the object, especially if they carry detailed depictions and are multicolored, will be perceived as double and fuzzy (dubitabilis). ${ }^{37}$

The next question is whether or not this explanation can be applied to the perception of more than one object at the same time. What happens when the eyes are focusing on one object, but another object, farther away, appears in the visual field? According to Alhacen, the form of that second object will be impressed upon the two eyes and will thus appear as two objects (i.e., as being located in two places at opposite ends with respect to the two eyes) and their form will be indeterminate (dubitabilis or non certificata). If, on the other hand, the additional object is quite small and close to the perceiver, then it is perceived as one. ${ }^{38}$ Moreover, the closer it is to the center of the visual 
axis, the more the form is perceived as determinate. But if the object is too close to the eye, this mixes up the visual angle and the object may be perceived as being larger than it actually is. ${ }^{39}$ In contrast, moving away from the object leads to some visible parts becoming hidden, and thus the clarity of visual perception is decreased. ${ }^{40}$

Misperception can also result from the relative positions of the eye and the object. Alhacen proposes illustrating this point with an experiment. He asks the reader to place a square piece of parchment with writing on it in front of the eyes and focus on the center of it: that section of the parchment is distinctly visible, whereas the rest of the writing on the parchment can certainly be seen, even though not with the same level of determinateness. ${ }^{41}$ Inclining the parchment thus decreases the legibility of whatever is written on it. What Alhacen is suggesting to the reader is to experiment with the limitations or restrictions of the optimal conditions for visual perception, which, for the surface of a reasonably sized object, must directly face the perceiver at a moderate distance. ${ }^{42}$ When the object is not properly oriented to face the perceiver, there is no accurate perception of it, but simply misperception, in the sense of perceiving the object as other than what it is.

We saw in the previous section that the optimal conditions for perception were mostly thought to pertain to the medium and the sense organs, but they can also fail to exist in the case of the object. For instance, the lack of opacity leads to misperception. If a colored object is placed behind a piece of glass, we perceive the glass as having the color of the colored object behind it or, in the case of stained glass, being a mixture of the two colors. ${ }^{43}$ However, in most cases the problems pertain to the conditions of the medium and the organs. The eye can be affected by an intense light so that it loses the capacity to perceive the color of an object to which it turns, and it perceives that object in a blurry manner. Or, when suffering from illness, the eyes fail to accurately perceive (thus, they 
misperceive) the actual colors of objects. ${ }^{44}$ The same problem occurs when perception takes place under the conditions of too dim a light, especially if the surface of the object has subtle features, or has many different colors, in which case it will appear as being of one color only. ${ }^{45}$ The size of the object is also important for its perceptibility: a very small object with small features, like a miniscule animal, can be perceived but only in an indeterminate way; for instance, some of its parts are not visible. ${ }^{46}$ Finally, the conditions of the medium that affect its transparency, like the presence of smoke or fog, foster misperceptions. In all these cases, perceptual error occurs because of absence of moderation in the conditions that make veridical visual perception possible. ${ }^{47}$

Alhacen makes an important additional qualification concerning these conditions, namely that they are not isolated from each other. Variations in one have implications for the way the others are or can be fulfilled. For instance, the appropriateness of distance is relative to the magnitude or color of the object, the conditions of the medium (illumination and transparency), and the state of the organ (health). ${ }^{48}$ When all of the preconditions have been fulfilled, they then constitute the ideal conditions for visual perception, but they must be understood in relation to real things in the world, as optimal conditions for perceiving this object by this perceiver in these circumstances. Cases of misperception are those in which those preconditions are not fulfilled.

\section{My Bad: Errors of Judgment}

We have seen that problems in transmission are one of the two major sources of perceptual errors. But the transmission of information under normal conditions and its reception by properly endowed sense powers does not suffice for a description of how visual perception takes place, and thus, it does not suffice in explaining all errors. Every perceptual experience 
requires the further processing of the information received, whatever its form, by a variety of other powers of the soul, the so-called internal senses. For our purposes, the most important of these are the common sense, the estimative power, and the cogitative power. $^{49}$

Perception does not concern random perceptual properties, but properties that jointly exist in a given thing (they are accidents that inhere in it), and thus, the perceptual process should account for the perception of that unified percept. A description of a perceptual experience in this conceptual framework must include the proper, common, and accidental sensibles. To the extent that some of the powers of the soul operate by means of discrimination and combination (discernere and diiudicare, functions of the common sense), which can be subsumed under the generic term "judgment," perception includes judgment..$^{50}$ It is notable, however, that judgment comes in degrees; we are here using the term in a broad sense that refers to operations that are part of perception and take place without our conscious effort. This should be distinguished from a narrow concept, which is related to propositional beliefs at the intellectual level of the soul. In any case, what matters for our purposes here is that perceptual judgment is an inherent source of errors.

In the same way as there is a hierarchy of powers that operate on different levels of abstraction, there are also different levels of perceptual judgment and, correspondingly, different kinds of perceptual errors. At the level of common sense, judgment takes, according to Avicenna, the form of "this mobile [thing] is black, and this red [thing] is sour. ${ }^{\prime 51}$ For Aristotle, the activity of combination is the most common source of error. He often contrasts this with the operation of apprehending simple terms by the intellect or proper sensibles by the external senses, which are always correct provided the necessary conditions are met. ${ }^{52}$ In the previous section, we considered some cases in which those 
conditions were not met; the present section focuses on what happens when the processing powers get things wrong.

\section{Internal senses mess things up}

A clear formulation of the role of the internal senses in accounting for errors of judgment can be found in Albertus Magnus's commentary on De anima:

However, in composing the sensibles, there is frequently a great deception: for instance, what the colored thing is (whether a golden-yellow thing is honey or yellow bile); or where the colored thing is; or what it is that makes a sound; or where it sounds; and so with the others. I will explain below that the reason for this is that the combining does not belong to an external sense but to some higher power, which makes the mistake. ${ }^{53}$

Each of the external senses transmits its proper sensible to the common sense and the other internal senses. Thus, when I see a duck and hear its quacking, the sense of sight apprehends a certain shape of color and the sense of hearing the sound it makes. The common sense is responsible for combining a unified representation of distinct sense modalities; its operation allows me to perceive a quacking duck. But the process is not infallible, and often the combination does not represent reality as it is. I may, for instance, fail to realize that the quacking belongs to the duck, and attribute it to some other thing in my visual field instead. Also, higher types of judgment bring uncertainty, for instance when a thing is recognized incorrectly. When I observe some yellow substance, I may mistakenly see it as yellow bile even though it is honey. ${ }^{54}$ (Or so medieval authors claim; we have no idea what yellow bile looks like, so it is unlikely that we will make this particular mistake.)

The examples that medieval authors have in mind are manifold: things on the shore seem to move when the subject is on a moving ship; stars seem to be immobile; when the eyeball is pressed with a finger, things appear as two (as seen above); an oar seems to bend in the water; a circle of fire appears when a torch is whirled around in the darkness; and so 
forth. On the other hand, imagination may occasionally distort our perceptions in such a way that we get the impression that imagined things appear as if they are present. This happens especially in feverish visions, in dreams, and under the influence of strong emotions. ${ }^{55}$ Finally, errors often emerge in relation to common sensibles of size and shape, as is clear on the basis of the classic examples of a square tower that appears round when seen from a distance and of the sun appearing to be four cubits wide. ${ }^{56}$

What all of these cases have in common is that the perceiving subject judges the external things in the world to be different than they really are. The psychological processes that account for binding together the different sense modalities, incidental perception, and perception of common sensibles are liable to go wrong because they are judgments made by fallible cognitive powers. The two internal senses that were usually held responsible for making these kinds of interpretations and judgments are the common sense and the estimative power (or, in certain cases, the cogitative power). In what follows, we examine in more detail some instances of the failure of these powers to execute accurate perceptions.

Let us begin with the common sense that is responsible for combining proper sensibles. Albertus Magnus explains that:

[...] for although in the composition of a color with a substance, or in the separation of a color from a substance, an error takes place, there is never a mistake concerning the color. For, sight always says that red is red, but to combine redness with a certain substance that is made of copper, or with a certain substance that is made of gold, does not belong to the sense of sight. It belongs to the common sense, as will be seen below. And in this composition and division, a deception often takes place; many have believed copper to be gold, and many have thought that honey is bile because both are yellow. ${ }^{57}$

Albertus begins with the claim that external senses never err concerning their proper objects - a claim that, as we have seen above, must be understood as referring to situations in which the conditions are satisfied. He then goes on to consider the possibility of misjudgment, which takes place when the common sense attributes the perceived property 
to a different thing than that to which it belongs in reality. The act of judgment, here expressed as combining or separating (that is, affirming or denying one thing of another), is explicitly assigned to the faculty of the common sense. ${ }^{58}$ Its operation counts as a judgment, although it is not based on conscious deliberation and does not count as a perceptual belief in a robust sense, which involves the use of rational powers of the soul (the Arisotelian doxa). The immediate and pre-conceptual judgment that a certain statue is made of gold and that a yellow substance is bile instead of honey does not have to be made consciously (although one can of course also form such a judgment more consciously as well). ${ }^{59}$ Instead, Albertus has in mind situations in which the association of two perceptual features of the perceived thing happens on its own (from the phenomenological point of view): we perceive a yellow substance as being bitter without necessarily forming the propositional thought, "This is bile." 60 The common sense is responsible for combining the two qualities when one and the same thing is perceived, and it does this on the basis of the information it receives from different external senses. Propositional thought and perceptual belief concerning the nature of the yellow stuff being honey or bile arise in the intellectual powers of the soul on the basis of perceptual content, but the perceptual content itself is formed independently by the internal senses. ${ }^{61}$

The emotional state of the subject may also radically affect the way perceptual content is interpreted and judged. External senses as such are not influenced, and the common sense does not make any mistakes in binding different perceptual qualities to one another. But, as we all know, "someone who is nervous and afraid, and a lover who is vehemently in love, are deceived to the extent that it seems to the fearful person that he sees enemies, and to the lover that she sees the loved one, just because of a very minor resemblance." ${ }^{\prime 62}$ The reason for this misjudgment can be found in the physiological changes 
that are the material aspect of emotions. ${ }^{63}$ The so-called animal spirits (spiritus animalis) run about in the brain in irregular ways, and this causes errors of judgment: ${ }^{64}$

[I]t seems to those who have fever, in whom the matter evaporates to the head, that they see animals on the wall, because randomly drawn lines on the wall resemble animals slightly. And indeed, those who are weakened in such a way that the use of reason is not hindered for them, struggle vehemently among themselves against phantasms, knowing that they are wrong [...] But if the affection of sickness is stronger, to the extent that it hinders reason, then the person is moved by the resemblance and becomes angry, frightened, or desirous, just like when the thing is present. ${ }^{65}$

The context in which Albertus makes these claims is related to the question of why things in dreams appear as if they were real. When one is asleep, the connection between rational judgment and the internal senses is blocked or disturbed due to the movement of animal spirits, and reason cannot intervene in the process. Other physiological states may also have the same effect when one is awake, but when the state of the perceiver is not overly bad, there is a mechanism that counterbalances the mistake. Reflective knowledge of one's own state allows one to make a correct rational judgment regardless of how the external world appears - just like knowledge in the case of seeing double due to pressure on the eyeball makes possible the judgment that there are not two things in reality, although it surely seems like there are.

Albertus explains that the difference between the two persons in the above-quoted passage is that the less sick one is able to make a rational judgment, while the one whose reason is blocked judges (iudicat) on the basis of the common sense or sensory estimation (sensu communi vel aestimatione sensibili). ${ }^{66}$ He compares this to the Aristotelian example, according to which the sun appears to be one foot in diameter although reason tells that is larger than the Earth, and he also explains that a similar non-veridical judgment is made when one crosses one's fingers and touches a piece of wax with the crossed fingers. If the 
only source of information is the sense of touch - the eyes are closed and so forth - the resulting judgment is that there are two distinct pieces of wax. However, if the eyes are kept open, one sees that there is only one piece of wax. Although the two senses give conflicting information, the sight is a nobler and more important sense for humans, and therefore the perceiver's final judgment is not erroneous. Yet, the sense of touch continues to suggest that there are two different pieces of wax. The mistake can be corrected without resorting to the higher rational capacities, but apparently it requires comparing the information from two external senses together in the common sense. It seems in the end to be a case of deferring to one sense over the other, as an instance of visual dominance.

These examples show that the error of judgment takes place in the common sense, or in the estimative power, depending on the particular case (and also on the author: some think that the honey/bile case is a mistake made by the common sense, while others locate it in the estimative power). These perceptual errors are rather common because they involve a sensory judgment that has a compositional structure, as it requires combining information from various sources. At the same time, these examples show that judgment can take place on various levels, from the external senses to the internal senses and reason.

\section{Perspectivist tradition on errors of judgment}

We have noted above how Alhacen explained that the perception of objects is affected by the conditions in the medium and the eye. Now, for Alhacen (and the perspectivists that followed), the reception of the proper sensibles of light and color are just a fraction of the visual properties that constitute what they called the "form of the object." In its totality, it includes some twenty additional visual intentions (the exact number varied from author to author): distance, spatial disposition, bodiliness, shape, size, continuity, discontinuity, 
number, motion, rest, transparency, opacity, darkness, roughness, smoothness, shadow, beauty, ugliness, similarity, and difference. ${ }^{67}$ An object is perceived properly only when all these properties are perceived, and Alhacen calls the process that makes us aware of them "perception by means of visual scrutiny." However, he makes clear that we do not need to actually perceive all of them in every case if the object is known to us from a previous encounter. In that case, our visual system picks up the most salient features of the object and proceeds to identify it on the basis of them. (Significantly, Alhacen never provides an example of what these salient features are, probably because he realized that it could easily turn into a discussion about which salient features are distinctive for a given kind/individual rather than about the principled justification for this kind of perception.)

Perhaps the most important element in this model is that visual perception always includes assimilating the incoming species of the object to a previously acquired form, so that the thing currently in view is perceived (or identified) as it really is-either as a certain individual thing, a representative of kind, or both. ${ }^{68}$ Whenever the conditions of transmission fail, this has inevitable consequences downstream in the process, meaning that the reception of inaccurate information will result in misperception. So, for instance, when someone known to the perceiver (say, Juhana) is seen at a great distance, the perceiver may fail to recognize him and mistake him for someone else (say, Filipe). Incommensurate distance results in mis-identification, which is an erroneous judgment of identity, ${ }^{69}$ in this case concerning an individual (Filipe rather than Juhana). But the same applies to the failed recognition of a kind, for instance when one confuses a donkey and a horse from a distance. ${ }^{70}$ Yet in other cases, it is both:

A threefold error occurs in the case of trees: according to individuals, according to common forms, and according to both. Hence, one almond tree is sometimes judged to 
be another one; or from a great distance a large pear tree sometimes appears to be an almond tree; or at times Peter's pear tree appears to be Martin's almond tree. ${ }^{71}$

Alhacen applies the same principle to the case of inferential reasoning. Perceiving something that is not really moving as being in motion, because something else moves near to it-like the moon behind thin clouds or a stick under moving water-is the consequence of immoderate distance. ${ }^{72}$ Similarly, objects far from each other can, when seen at great distance, be judged as being contiguous to one another. ${ }^{73}$ This misjudgment falls under the category of perceptual inferential errors because distance can only be perceived by means of inference-so, all visual perceptions that depend on the perception of distance depend on inference.

Misperception can also result from a faulty spatial disposition, which leads to the cognitive power judging incorrectly about the size, shape, and even color of the object. ${ }^{74}$ This occurs when the object is tilted or inclined. Moreover, if the perception of an objectits form-is based solely on the perception of the parts that are visible to the perceiver, rather than on the all perceptual parts, the final perception will be inaccurate. ${ }^{75}$ That is the case with objects with many equal sides facing the perceiver, which, when perceived at a great distance, will be perceived as being round because the corner segments will not be perceived. ${ }^{76}$ Alhacen probably had in mind the square tower example, although he only refers to this example in the context of the incorrect perception of size. ${ }^{77} \mathrm{~A}$ later perspectivist, Roger Bacon (1214-92), illustrates this problem with the example (also found in Alhacen) of a solid and colored object seen through a thin multi-colored cloth: if the spaces between the threads of the cloth are sufficiently large, then the perceiver will be able to distinguish between the color of the partly absconded object and the colors of the 
cloth itself; but if the openings in the cloth are very small, the color of the object will get mixed with the colors of the threads and thus be misperceived. ${ }^{78}$

Similarly, distance (proportional to the size of the object) also leads to a failure in distinguishing between parts of an object, or else leads to a judgment that there is a division when there is in fact none. For instance, if part of a distant wall has been painted black, we will perceive a gap in the wall, a hole, or a discontinuity, none of which actually exist in the wall itself. ${ }^{79}$ Now, whereas in some of these cases it seems that there is no erroneous judgment, but that things are simply perceived as being a certain way, other cases make it clear that perceptual error is the result of a faulty inferential procedure. This is well illustrated in the case of the misperception of motion due to an inordinate distance. Imagine, Alhacen asks the reader, that you move in the direction of the moon and, despite your speed, you never seem to get closer to it. Thus, you infer that the moon is moving away from you at least at an equal speed. The premise behind this inference is taken from your experience with everyday objects: if you move in the direction of a static object, e.g. a tree, you get closer to it; if you do not get closer to that particular object, then the object must be moving away from you. ${ }^{80}$ The misperception is the result of an unconscious inference from premises known to the perceiver (ex propositionibus iam dudum animo notis infertur sillogistice motio) and applied incorrectly due to the incommensurate distance to the object. ${ }^{81}$

Alhacen's list continues, but for our purposes it suffices to note that for him, perception is riddled with the potential of failing to grasp things as they are. Alhacen seems to indicate with his lengthy investigation into the topic that the optimal conditions for perception are so stringent that they cannot always be met, thus making perceptual errors a frequent part of our everyday experience. It is here that we find what probably is the major 
difference between the perspectivist and the Aristotelian model of visual perception: the former is concerned with making error an inevitable, and thus, important part of a theory of perception, and likewise with providing a basic explanatory framework that applies to all sorts of cases of misperception.

\section{Skeptical worries}

As we have seen above, medieval thinkers assumed that no particular justification is needed for the veracity of perception. If external conditions are right and the internal senses operate as they should, the resulting perceptual experience will make the perceiver aware of things as they really are in the world. However, in the early fourteenth century some authors started to question whether perception justifies a belief in the existence of the perceived object.

Skepticism about perception had never been completely absent from philosophical discussions, ${ }^{82}$ but it rose to a new height when Peter Auriol (1280-1322) presented his novel theory of cognition, in which sensory illusions have a central explanatory role. Authors such as Walter Chatton (1285-1343) and Adam of Wodeham (1298-1358) criticized his theory by arguing that it gives us no firm ground to claim that perception is ever reliable. In the context of the present essay, the interest in this dispute is twofold. First, it reflects a major change in the nature of the discussion about perception, a move away from the transmission of information via species and towards a development of more robust representationalist theories of perception under the guise of intentional cognitive acts. Second, as many modern scholars have pointed out, it reveals a shift in the largely unquestioned traditional belief in the reliability of perceptual experience under normal conditions. ${ }^{83}$ 
Peter Auriol's theory is based on the idea that if we understand the mechanism of illusions, we are in a better position to understand how veridical perception takes place because of the fact that these two cognitive processes share a fundamental feature: with both of them, something appears to the subject. Auriol's original aim was to show that the intellect is a formative power, one capable of putting its object in what he calls the "apparent being" or "intentional being" (esse apparens, esse intentionale), and for that reason he compares it to the senses. His argument is that if the external senses are capable of forming or producing the thing cognized in apparent or intentional being, then the intellect is much more capable of doing so. ${ }^{84}$ Perceptual illusions are extreme, but illustrative, examples of the formative capacity, because they show that our senses are capable of producing such intentional being even when the thing is not as it appears to bethat is to say, when there is a difference between the real extra-mental being of the thing and the way it appears to the perceiver.

Auriol makes this appearance the defining feature of cognition. ${ }^{85}$ According to him, cognition means nothing more than that some $X$ appears to subject $S .{ }^{86}$ Though he develops this idea by considering altogether eight different perceptual illusions, the most important for our purposes are the four following perceptual illusions:

(1) from a moving boat, the trees on the shore are perceived as moving;

(2) if a (burning) stick is moved in a circular motion, one perceives a circle (of fire);

(3) a half-submerged stick in water is perceived as bent/broken;

(4) sometimes the feathers on a pigeon's neck appear to be colored. ${ }^{87}$

None of these examples are new, but the role that Auriol gives to them in his theory is original. In all of these cases, there is no doubt that we objectively perceive these properties, but the perceived property does not exist in the object, at least not in the way 
that it appears to be. In his view, what we perceive is the appearance of a thing or a thing having an apparent and intentional being.

For Auriol, then, whatever appears to us in the case of illusions has an apparent being, in other words, the thing as it appears to me. He extends this observation to the cases of veridical perception. When a tree is in front of me and my eyes are open, my act of vision puts the tree into apparent being and this explains why I become aware of the tree. This apparent being is simply the result of the cognitive power's bringing the object into focus. As Dominik Perler puts it, it is nothing other than "the real thing itself insofar as this thing assumes a certain function, namely to be the intellect's object." 88 Perler writes about intellectual cognition, but the same process also takes place when something is perceived through the external senses. As a matter of fact, all cognitive powers of the soul function in the same way, and it makes no difference whether the object is really present or not or whether it really is such as it appears to be. Auriol makes this point clear when he describes how external senses and imagination are formative powers: they put the thing in apparent/intentional being, as, for instance, "when my father is imagined by me, he is put in intentional being." ${ }^{19}$

It is not difficult to see why this theory prompted later thinkers to criticize that it leads to extreme skepticism. They took Auriol's apparent being to mean that cognitive powers create internal representations that function as objects for the cognitive powers. In a sense, their criticism seems justified because, for Auriol, the difference between veridical and non-veridical perception is that in the former both the object and the representation are present, whereas in the latter only the thing in apparent being is present, although we believe that we are perceiving an external object. In that case, so the argument from illusion goes, should we not conclude that both in veridical and non-veridical cases all we perceive 
are the internal representations? In other words, Auriol's theory explains veridical perception of an unmoving stick and non-veridical perception of a circle in the air made by a rotating stick exactly in the same way. The circle I see is not really there, but it appears to be there because my sense of sight puts it (whatever this "it" is) into apparent being. Likewise, my sense of sight puts the unbent and unmoving stick into apparent being. What grounds the difference between the two cases?

The objections by Walter Chatton and Adam of Wodeham stem precisely from the fact that Auriol's theory does not seem to provide any way to distinguish between nonveridical and veridical perception. Whether these worries were grounded in a correct interpretation of the theory has been the subject of intense scholarly debate. Dominik Perler, Russel Friedman, and Han Thomas Adriaenssen have all emphasized Auriol's realist tendencies. ${ }^{90}$ According to them, the thrust of his account is precisely to reject the existence of any sort of mental representation that would be the object of perceptual experience. Supporting their reading is Auriol's claim that the apparent being is not a species, since if it were, then the cognitive power would have to be reflexive and the species (rather than the external thing) would be the immediate object of the cognitive act. ${ }^{91}$ It would be an internal representation that constitutes a veil or a blindfold (pallium), which prevents our having access to the external world. Auriol is explicit that in that case, "knowledge (scientiae) would not be of things but of such idols." 92

The reason why perception is about an external thing rather than about the thing in apparent being is that the thing in apparent or intentional being is not something absolute and real, but rather something that has only a diminished being. ${ }^{93}$ Moreover, Auriol notes, the soul does not distinguish between the thing in apparent being and the thing in real being-much in the same way as an internal representation and an external thing (which is 
perceived by means of the representation) cannot be distinguished in Augustine's trinity of the outer man. ${ }^{94}$ As Friedman puts it, "it is intrinsic to each and every thing to have two different modes of being: real or extramental being on the one hand, and intentional or objective being on the other." 95 Their different modes of being do not stand in the way of cognition because they are one and the same (sunt idem). ${ }^{96}$ The numerical unity makes Auriol's theory a version of direct realism: there is only one thing, the real extramental object. This object has a real being in and of itself, but it also has a potentiality for apparent being - a potentiality that can be actualized by a cognitive subject.

The problem with this interpretative line of reasoning-and with Auriol's own explanation-is that it works perfectly well in the case of veridical perception, as there is a thing with a real being that is put into apparent being. Things seem more complicated in the case of non-veridical perception. Scholars such as Perler have argued that this does not alter the general picture, as perceptual errors simply denote a defect in the apprehension of the extra-mental thing ("a distorted perception" is how Perler puts it). ${ }^{97}$ But this does not explain much: an explanation should say why we fail to apprehend how things are. Why do certain cognitive processes result in a distorted perception while others do not? This issue is particularly pressing in the case of Auriol, because the whole point of making the object of a cognitive act be a thing in its apparent being arises as a way to explain illusions and veridical perceptions by the same process. ${ }^{98}$ The problem in Auriol's account is that he takes the thing in apparent being to be the way the world is presented as being, when there is a world that is that way. But there is no way to know, on the basis of the experience itself, whether its content corresponds to the way things are beyond the way they appear to be. In fact, it is even difficult to understand whether it is possible to have access to the knowledge by which power (sense, imagination) is putting the thing into apparent being in a given situation. ${ }^{99}$ 
Consider Auriol's examples of the stick. It is easy to accept that the apparent being of the stick is numerically one with the real being of the stick when the content of perception is identical with reality. To put the stick into apparent being is simply to make it appear to me, and this process is grounded in there being a stick in the first place. But how about the perception of a circle created by a rotating stick? Auriol argues explicitly that the circle that appears in the air does not have a real being in the stick, as that would mean that the stick is circular. So, if the process is the same both in non-veridical and veridical perception, then the circle that appears is the esse apparens either of (1) the stick or of (2) a nonexistent circle. If it is the apparent being of a nonexistent circle, then at least some cases of nonveridical perception are in fact cases of the perception of nonexistent things. On the other hand, if it is the apparent being of the stick, then Auriol would need to explain what grounds a thing's appearing to the subject in a one particular way rather than in another when the thing is other (straight) than how it appears to be (bent or broken when submerged in water, or circular).

In order to account for this difference, one would have to suppose that the object, for instance the stick, must have, in addition to its real being, as many potentialities for apparent being as there are ways in which it can be perceived. Such a theory would be committed to the view that the real being of the object is numerically identical not only with the veridical apparent being, but also with every non-veridical way in which it can appear to be-there would be a numerical unity without a formal unity, so to speak. A stick would need to have the potentiality, actualizable via cognitive power, to appear as being broken, as being a circle, and so forth. How many such potentialities would it be necessary to posit? Furthermore, and perhaps more importantly, we may ask what the metaphysical grounding of these potentialities is. It seems doubtful that all possible apparent beings would be 
numerically the same as the real being of the stick. That would be like saying that every object has the potentiality for appearing to be in all the ways it is not. Auriol's theory seems to lead to this problematic conclusion.

In light of these issues, it is quite legitimate to ponder whether Chatton's and Wodeham's criticism is justified. So long as Auriol does not provide any explanation for the difference between veridical and non-veridical perception, it seems only fair to ask whether we are justified in believing that any given experience is veridical. As we understand it, Auriol's theory is unable to do this, and thus it is difficult to decide whether subsequent critiques of his view hold any water. ${ }^{100}$ If all I have primary access to is $X$ appearing to me, I am in no position to know whether $X$ really is as it appears to be-and ultimately whether there is an $X$ out there in the first place. I can never know for certain what causes a thing to appear to me as being such and such.

Auriol's analysis of misperceptions differs from the earlier authors that we discussed above, not only because he considers perceptual errors to be paradigmatic cases that help us to understand what perception (or in general, cognition) is, but also because he offers no explanation for them. When we see a circle or a bent stick, no transmission errors take place. But according to Auriol, our cognitive apparatus does not make a mistaken judgment either. It seems to us that his critics were partially puzzled exactly by this inability to locate the problem. If we cannot tell, even theoretically, where the "mis-" in misperception arises from, are we really in a position to say that veridical perception is reliable? Although Auriol may have had a ready answer to this concern, he does not reveal it, and thus it is understandable that certain skeptical worries emerge in relation to his theory. 


\section{Conclusion}

By providing a systematic overview of medieval discussions concerning perceptual errors, this paper shows that late medieval philosophers took the difference between veridical and non-veridical perception seriously and that they were aware of the need to provide theoretical explanations for the latter. Although their explanatory framework was quite different from ours, they nevertheless grappled with similar phenomena as are present in our experience of and relation with the external world. They knew, as we do, that things are not always perceived as they really are, and in order to retain the ultimate trust in the senses, they entered into a systematic specification of the conditions, under which experiences can safely be assumed to be veridical.

Our analysis is based on a distinction between two major kinds of problems that may hinder veridical perception: problems of transmission and problems of judgement. The boundary between these two groups is not always clear, because the concept of "judgment" is highly versatile in the hands of medieval authors. It is not always clear what should be included in perceptual judgment and the extent to which the operations of the different cognitive powers involved in perceptual processes are distinct from each other. The concept of judgment was used to refer to operations of the external senses, the internal senses, and the intellect, and from this perspective some transmission errors seem to belong to this group.

However, by using this division as a heuristic tool we have hopefully been able to show that medieval authors gave different explanations for different kinds of perceptual errors. On the one hand, they elaborated on environmental conditions (a transparent and 
properly illuminated medium with no disturbances to it), on conditions of the object (proper size, opaqueness, the correct position relative to the perceiver), and on conditions of the perceiver's bodily sense apparatus (organs must be in a proper state and healthy). On the other hand, many conditions that they discussed concerned the general state of the perceiver, her/his emotions, and the more complex functions of the whole psychological apparatus, as well as previous experiences that allow her/him to recognize and classify things around her/him more easily.

Despite their interest in perceptual errors, medieval authors were generally optimistic about the reliability of the senses because they thought perception was explainable in the same way as any other kind of change: by being grounded on the nature of things. They thought that we are usually capable of distinguishing perceptual errors from cases in which there are no problems, and that most of the time we can trust the accuracy of our perceptions. Only when our ability to check the conditions themselves (via other senses, reason, experience) is hindered, are we utterly misled by them. This realistic framework was questioned, to some extent, by Peter Auriol. Regardless of how the details of his theory are understood, it constitutes a new way of regarding perception that went against many traditional theories of perception. It was based on the assumption that there is no difference between veridical and non-veridical perception when it comes to the mechanism of perception. His critics, Chatton and Wodeham, charged him with opening the gate for skepticism to enter in. They tried to return to the traditional model by claiming that we can locate the problem in the process of judgment. But the field had already changed.

On the other hand, explaining misperception by appealing to errors of judgment may be nothing more than naming them. Even if the ultimate explanation for perceiving things as being different than they are in reality is based on the activity of the common sense-in 
combining elements incorrectly-we may still ask why it does so in some cases and not in others. It seems that perspectivist theories give a plausible answer to this question: our previous experiences explain why we sometimes misperceive things. This idea is inbuilt into the Aristotelian view too, but one might claim that perspectivists provide a more developed picture.

Analyzing medieval theories of perception from the point of view of the explanations that they give for problematic cases sheds light on them from an interesting perspective. It allows us to see more clearly the limits of these theories, and to point out certain fundamental philosophical presuppositions that underlie them. Occasionally focusing on the negative reveals the positive more pronouncedly.

\section{Bibliography}

Adriaenssen, H.T. (2017a) "Peter Auriol on the Intuitive Cognition of Nonexistents: Revisiting the Charge of Skepticism in Walter Chatton and Adam Wodeham," Oxford Studies in Medieval Philosophy 5, pp. 151-180. Press.

(2017b) Representation and Scepticism from Aquinas to Descartes, Cambridge University

Albertus Magnus (1890) 'De somno et vigilia,' in A. Borgnet (ed.), Alberti Magni Opera Omnia 9. Paris: Vivès.

(1968) De anima, in C. Stroick (ed.), Alberti Magni Opera Omnia 7.1. Aschendorff:

Monasterii Westfalorum.

(2008) De Homine, in H. Anzulewicz and J.R. Söder (eds.), Alberti Magni Opera Omnia 27.2. Aschendorff: Monasterii Westfalorum.

Alhacen (2001) De aspectibus, in A. Mark Smith (ed. and trans.), Alhacen's Theory of Visual Perception, Philadelphia: American Philosophical Society.

Aristotle (1984) The Complete Works of Aristotle: The Revised Oxford Translation, 2 vols. in J. Barnes (ed.), Bollingen Series 71/1-2. Princeton: Princeton University Press. [= De anima (=DA); De sensu (= Sens.); Metaphysics (= Met.); De insomniis (=Insomn.); Sophistical Refutations (= SE)]

Aristotle (2003) On the Parts of Animals I-IV, trans. with introduction and commentary by James G. Lennox. Oxford: Clarendon Press.

Averroes (1953) Commentarium Magnum in De anima, in F.S. Crawford (ed.), Cambridge, MA: The Medieval Academy of America.

Avicenna (1968) Liber de Anima Seu Sextus de Naturalibus, in S. Van Riet (ed.), Vol. IV-V. Louvain/Leiden: Éditions Orientalistes/Brill.

Biard, J. (2007) "Intention and Presence: The Notion of Presentialitas in the Fourteenth Century," in

S. Heinämaa, V. Lähteenmäki, and P. Remes (eds.), Consciousness: From Perception to Reflection 
in the History of Philosophy, Studies in the History of Philosophy of Mind 5, Dordrecht: Springer, pp. $123-140$.

Boethius (1867/1966) De institutione musica, in G. Friedlein (ed.) Anicii Manlii Torquati Severini Boetii De institutione arithmetica libri duo, De institutione musica libri quinque, accedit Geometria quae fertur Boetii, Leipzig: Teubner; reprint Frankfurt, Minerva.

(1989) Fundamentals of Music, in C. Palisca (ed.), C. Bower (trans.), New Haven: Yale University Press.

Bower, C.M. (2008) "The Transmission of Ancient Music Theory into the Middle Ages," in T. Christensen (ed.) The Cambridge History of Western Music Theory, Cambridge: Cambridge University Press.

Charles, D. (2000) Aristotle on Meaning and Essence. Oxford: Oxford University Press.

Cicero (1967) Academica, in H. Rackham (trans.) Cambridge, MA/London: Harvard University Press/William Heinemann LTD.

Corcilius, K. (2014) "Activity, Passivity, and Perceptual Discrimination in Aristotle," in José Filipe Silva and Mikko Yrjönsuuri (eds.), Active Perception in the History of Philosophy. Dordrecht: Springer, pp. 31-53.

Denery, D. (2005) Seeing and Being Seen in the Later Medieval World, Cambridge MA: Cambridge University Press.

Di Martino, C. (2008) 'Ratio particularis,' Doctrines des senses internes d'Avicenne à Thomas d'Aquin. Études de philosophie médiévale 94, Paris: Vrin.

Dyer, J. (2009) "Speculative 'Musica' and the Medieval University of Paris," Music and Letters 90:2, pp. 177-204.

Ebert, T. (1983) "Aristotle on what is done in perceiving." Zeitschrift für philosophische Forschung 37:2, pp. 181-93.

Friedman, R.L. (1997) In Principio Erat Verbum: The Incorporation of Philosophical Psychology into Trinitarian Theology, 1250-1325, PhD dissertation, University of lowa.

(2015) "Act, Species, and Appearance: Peter Auriol on Intellectual Cognition and Consciousness," in G. Klima (ed.) Intentionality, Cognition, and Mental Representation in Medieval Philosophy, pp. 141-165, New York: Fordham University Press.

Harvey, R.E. (1975) The Inward Wits: Psychological Theory in the Middle Ages and the Renaissance, London: The Warburg Institute, University of London.

John Blund (2012) Treatise on the Soul, D.A. Callus and R.W. Hunt (eds.), M.W. Dunne (trans.) Oxford: Oxford University Press.

John Buridan (1516) Quaestiones super De sensu et sensato, in G. Lokert (ed.) Quaestiones et decisiones physicales, fol. $27 \mathrm{r}-34 \mathrm{v}$, Paris.

Quaestiones super De sensu et sensato. Vatican, BAV Vat.lat. 11575, fol. 88ra-88vb, 92ra109rb.

Quaestiones super De sensu et sensato. Erfurt, Universitätsbibliothek, Dep. Erf., CA $2^{\circ} 357$, fol. 132ra-149va (olim 131ra-148va).

John Duns Scotus (1950-2013) 'Ordinatio', Opera Omnia. Civitas Vaticana: Typis Polyglottis Vaticanis. John Pechkam (1970) Perspectiva communis, in D.C. Lindberg (ed.) John Pecham and the Science of Optics, Madison: The University of Wisconsin Press.

John of la Rochelle (1995) Summa de Anima, in J.G. Bougerol (ed.) Textes Philosophiques du Moyen Âge 19, Paris: Vrin.

Johnstone, Mark A. (2015) "Aristotle and Alexander on Perceptual Error," Phronesis 60, pp. 310-338.

Kaukua, J. (2014) "Avicenna on the Soul's Activity in Perception," in J.F. Silva and M. Yrjönsuuri (eds.), Active Perception in the History of Philosophy: From Plato to Modern Philosophy, pp. 99116. Studies in the History of Philosophy of Mind 14. Dordrecht: Springer.

Knuuttila, S. (2004) Emotions in Ancient and Medieval Philosophy, Oxford: Clarendon Press. 
(2008) "Aristotle's Theory of Perception and Medieval Aristotelianism," in S. Knuuttila and P. Kärkkäinen (eds.) Theories of Perception in Medieval and Early Modern Philosophy, pp. 1-22. Dordrecht: Springer.

Lagerlund, H. (2010). "A History of Skepticism in the Middle Ages," in H. Lagerlund (ed.), Rethinking the History of Skepticism: The Missing Medieval Background, Studien und Texte zur Geistesgeschichte des Mittelalters 103. Leiden: Brill, 2010, pp. 1-28.

Licka, L. "Perception and Objective Being: Peter Auriol on Perceptual Acts and their Objects," American Catholic Philosophical Quarterly 2016, Vol. 90, No. 1, pp. 49-76.

Lindberg, D.C. (1976) Theories of Vision: From Al-Kindi to Kepler, Chicago: The University of Chicago Press.

Lloyd, G.E.R. (1968) Aristotle: The Growth and Structure of His Thought, Cambridge University Press. Nussbaum, M. and Rorty, A., eds. (1992) Essays on Aristotle's De anima, Oxford: Clarendon press.

Oelze, A. (2018) Animal Rationality: Later Medieval Theories 1250-1350, Investigating Medieval Philosophy, Leiden/Boston: Brill.

Pasnau, R. (1997) Theories of Cognition in the Later Middle Ages, Cambridge: Cambridge University Press.

(2002) Thomas Aquinas on Human Nature: A Philosophical Study of Summa Theologiae la 75-89, Cambridge: Cambridge University Press.

Perler, D. (1994) "What Am I Thinking About? John Duns Scotus and Peter Auriol on Intentional Objects," Vivarium 32:1, pp. 72-89.

(2008) "Seeing and Judging," in Simo Knuuttila and Pekka Kärkkäinen (eds.), Theories of Perception, Dordrecht: Springer, pp. 151-69.

(2014) "Can We Trust Our Senses? Fourteenth-Century Debates on Sensory Illusions," in D. Denery, K. Ghosh, N. Zeeman (eds.), Uncertain Knowledge. Scepticism, Relativism, and Doubt in the Middle Ages, pp. 63-90. Turnhout: Brepols.

(2015) Oxford Handbook of Philosophy of Perception, in Mohan Matthen (ed.). Oxford: Oxford University Press, pp. 51-65.

Peter Auriol (1952/56) Scriptum super Primum Sententiarum, 2 vols, in E.M. Buytaert (ed.). St. Bonaventure, NY: Franciscan Institute Publications.

Peter Auriol (2009) Scriptum super primum Sententiarum, in R. L. Friedman, L. O. Nielsen, C. Schabel (eds.) Electronic Scriptum. http://www.peterauriol.net/editions/electronicscriptum/contents/

Peter Olivi (1922/24/26) Quaestiones in secundum librum Sententiarum, 3 vols, in B. Jansen (ed.), Bibliotheca Franciscana Scholastica Medii Aevi 4-6. Florence: Collegium S. Bonaventurae.

Roger Bacon (1937) Liber de sensu et sensato in R. Steele (ed.), Opera hactenus inedita Rogeri Baconi 14, Oxford: Clarendon Press.

(1983) De multiplicatione specierum, in D.C. Lindberg (ed. and trans.) Roger Bacon's Philosophy of Nature, Oxford: Clarendon Press.

(1996) Perspectiva, D.C. Lindberg (ed. and trans.), in Roger Bacon and the Origins of Perspectiva in the Middle Ages, Oxford: Clarendon Press.

Sabra, A.I. (1978) "Sensation and Inference in Alhacen's Theory of Visual Perception," in P.K. Machamer, R.G. Turnbull (eds.), Studies in Perception: Interrelations in the History of Philosophy and Science, pp. 160-185, Columbus, Ohio State University Press.

Silva, J.F. (2014) "Medieval Theories of Active Perception: an overview," in F. Silva, M. Yrjönsuuri (eds.), Active Perception in the History of Philosophy, Dordrecht: Springer, pp. 117-146. (2017) "Perceptual Judgment in Late Medieval Perspectivist Psychology," Filosoficky Casopis. Special Issue on Perception in Scholastics and Their Interlocutors 2, pp. 29-60.

Smith, A.M. (2015) From Sight to Light: The Passage from Ancient to Modern Optics, Chicago \& London: University of Chicago Press.

Tachau, C. (1988) Vison and Certitude in the Age of Ockham: Optics, Epistemology and the Foundations of Semantics 1250-1345, Leiden: Brill. 
Thomas Aquinas (1888-1906) Summa Theologiae. Opera omnia iussu impensaque Leonis XIII P. M. edita, vols. 4-12, Rome: Typographia Polyglotta. (= ST)

(1984) Sentencia libri De anima, in R.A. Gauthier (ed.), Opera omnia iussu Leonis XIII P.M. edita, 45.1. Rome/ Paris: Commissio Leonina/Vrin.

(1985) Sentencia Libri De Sensu et Sensato, Opera Omnia Iussu Leonis XIII P.M. Edita 45.2.

Rome/Paris: Commissio Leonina/Vrin.

Thomsen Thörnqvist, C. "Aristotle and His Early Latin Commentators on Memory and Motion in Sleep." Forthcoming.

Toivanen. J. (2011) "Peter of John Olivi on the Psychology of Animal Action," Journal of the History of Philosophy 49(4), pp. 413-438.

(2013) Perception and the Internal Senses: Peter of John Olivi on the Cognitive Functions of the Sensitive Soul, Leiden: Brill.

William of Ockham (1982) Quaestiones in Librum Tertium Sententiarum (Reportatio), F. Kelly, G. Etzkorn (eds.), Guillelmi de Ockham Opera Theologica VI. St. Bonaventure NY: St. Bonaventure University.

Wood, R. (1982) "Adam Wodeham on Sensory Illusions with an Edition of 'Lectura Secunda', prologus, quaestio 3," Traditio 38, pp. 214-52.

\section{Notes}

\footnotetext{
${ }^{1}$ The authors are listed in alphabetical order and both are the principal authors. This research has been funded by the European Research Council under the Starting grant agreement n. 637747 for the project Rationality in Perception: Transformations of Mind and Cognition 1250-1550 (J.F. Silva) and the Riksbankens Jubileumsfond (J. Toivanen).

${ }^{2}$ For a general overview of Aristotelian theories of perception in the Middle Ages, see Knuuttila 2008; for an overview of active theories of perception, see Silva 2014.

${ }^{3}$ The nature of this information and the manner in which the perceiver acquires it can be, and has been, understood in various ways in the period under consideration, but that is not the focus of this paper.

${ }^{4}$ De Anima II.12, 424a17-21.

${ }^{5}$ De Anima II.5, 416b32-417a1 (emphasis added).

${ }^{6}$ In the present context, we will not consider cases where nonexistent things are cognized. That is to say, we focus on perceptual errors and illusions, and we rule out hallucinations and dreams, which are not episodes of perception proper, since the perceiver is not in a relevant causal relationship with any external object. This condition is emphasized in Johnstone 2015: 322-23.

${ }^{7}$ De Anima III.3, 428b18-22; see also De Anima II.6, 418a7-17; De Anima III.6, 430b29-30; DS IV, 442b8-10; Met. IV.5, 1010b1-3; Lloyd 1968: 194. Medieval authors usually understood this along the lines of Averroes's interpretation, that sight does not err whether it is seeing white or black, and hearing does not err whether it is hearing a high or low voice. Averroes 1953: 2.63, 224-25.

${ }^{8}$ De Anima III.3, 428b18-19. For a defense of a reading that Aristotle admits misperceptions also when the conditions are not optimal, see Johnstone 2015: 313-19; see also Charles 2000: 118ff.

${ }^{9}$ This attitude has been dubbed 'epistemic optimism' (Adriaenssen 2017: 249-46). See also Perler 2014.

${ }^{10} \mathrm{~A}$ distinction between two kinds of judgments (discrimination in the external senses and judgment at the higher level) is often made in the secondary literature. See, e.g., Ebert 1983: 181-93; Corcilius 2014: 31-53.

11 "Patet igitur sensum circa sensibilia propria non errare; sic enim est visus coloris et auditus soni et gustus saporis [...] Tactus autem plures habet differentias, quae non ad unum proprium sive commune genus reducuntur, tamen in unaquaque iudicat de illis et non decipitur. In compositione tamen sensibilium magna frequenter est deceptio sensum non contingit errare circa proprium sensatum. [...] Et causam huius infra dicemus esse quoniam sensus proprius non habet componere, sed aliqua superior potentia, et illius est error." (Albertus Magnus 1968: II.3.5, 103.) See also Thomas Aquinas, ST I.17.2.

12 On this, see Smith 2015: 316-21.
} 
13 “[...] nihil agat in distans nisi prius agat in medium; sed sensibile distans a sensu agit in sensum, igitur prius agit in medium. Illud autem causatum in medio est species, igitur etc. Minor patet per Aristotelem et Augustinum, qui dicunt quod sensibile agit in sensum." (William of Ockham 1982: q. 2, 44.)

14 On Ockham's rejection of the species, see Tachau 1988: 130-35.

15 Thus, species in this epistemological sense should not be confused with the taxonomic term that refers to different species under a certain genus.

${ }^{16}$ Although generally accepted, this theory was also criticized. Peter Olivi and Ockham are the most well-known critics of the species doctrine. For a discussion, see Pasnau 1997: 161-94; Tachau 1988: 3-81; Toivanen 2013 : 115-222.

${ }^{17}$ The famous dispute concerning Aristotelian philosophy of the mind focuses on the nature of this change. See Nussbaum and Rorty 1992.

18 “[...] spiritualius esse est coloris in medio quam soni et iterum spiritualius est esse soni in medio quam odoris. Et ideo ventus non aufert vel affert colores, sed bene obtundit auferendo sonos in parte et non in toto; odores autem et affert et aufert in toto, sicut dicit Avicenna et veritas per experimenta attestatur." (Albertus Magnus 1968: II.3.6, 106.)

19 "Alia suppositio est quod de unoquoque simplici existente melius iudicamus quam si esset alteri commixtum. Unde quando lumen solis transit in mane per fumos a terra elevatos, non iudicamus bene de eius luce seu de eius claritate, sed apparet nobis rubeus." (John Buridan 1516: q. 21, 39rb; Toivanen has emended Lokert's edition with readings from two manuscript sources, which are listed in the bibliography.) For stained glass, see, e.g., Peter Olivi 1922: q. 37, 667; Peter Olivi 1924: q. 58, 506.

20 "[E]t similiter laborantibus, id est febricitantibus, omnia videntur esse amara, propter hoc quod senciunt per linguam plenam humiditate huiusmodi, scilicet cholera amara." (Thomas Aquinas 1984: II.21, 157). See also Thomas Aquinas, ST I.75.2; 85.6, and Aristotle, De Anima II.10, 422b7-9.

${ }^{21}$ One possible way of reading the explanation, which is based on the tongue being filled with bitter moisture, is that it refers to an error due to the medium, not the organ. If the idea is that the taste of an object is transmitted to the organ (tongue) via saliva, and the saliva of a sick person is bitter, then the case is similar to a sun that is seen through fog: the medium affects the quality that goes through it. Medieval authors were not clear on this point, as they usually just said that the tongue is filled with bitter moisture, without explaining in detail whether they meant the saliva on the surface or moisture inside the tongue.

22 "Secundum quod unus et idem sonus videtur esse concinnus uni audienti et absurdus alii, non est propter naturam ipsius soni, immo propter diversitatem dispositionum in audientibus [...] Si autem audiens sit in debita consistentia existens, debite temperatus, debitam proportionem et commensurationem humorum habens, videbitur ei sonus concinnus, et erit ei delectabilis cum dispositione audientis propter adequationem ipsius in commensuratione; et ille idem sonus in eadem equalitate existens erit inconcinnus homini intemperato [...]" (John Blund 2012: 12, 88-89; trans. M.W. Dunne.)

${ }^{23}$ Boethius's influential work De institutione musica conveys this view in the form of a story about how Pythagoras found the mathematical ratios of harmonies. See Boethius 1867/1966: I.10, 196-98; Boethius 1989: 17-19. For the historical reception of Boethius's theory, see Bower 2008: 136-67; Dyer 2009: 177-204.

24 Peter Olivi 1924: q. 70, 633; Toivanen 2011, 428-35.

25 "Si enim digitus supponatur oculo, ita quod situs oculi mutetur, unum duo videbitur [...] unde si tunc supponamus illum esse detentum, ita quod non contradicat ei quod apparet, tunc in veritate dicet unum esse duo, et decipitur. Si autem non sit detentus, sed iudicet esse simulacrum in sensu tantum et non in re existens, tunc non decipitur: quia non videtur ei esse verum secundum rationem quod apparet in sensu." (Albertus Magnus 1890: II.2.3, 173b; see Aristotle, Insomn. III, 461b30-62a3.) For a discussion on this point, see Thomsen Thörnqvist (forthcoming).

26 "Solutio potest dici quod si hoc apparet magis album et illud magis nigrum, non sequitur quod aliquod illorum perfectius sentiatur, quia forte hoc apparet plus album quam sit et illud plus nigrum quam sit, et hoc esset decipi et non perfecte sentire." (John Buridan 1516: q. 21, 39vb.)

27 The idea may originate in perspectivist theory. Bacon refers to the Perspectiva and writes: "Si vero sunt sensibilia diversarum specierum ut album et nigrum, tunc intelligendum est quod opposita juxta se posita magis apparent [...] quoniam si sint equales quilibet apparet major quam sit et quam quilibet per se apparet. Et si sint inequales, ut major albedo minor nigredo, tunc illa nigredo non occultabitur quin videatur, set major videbitur quam sit et quam per se esset, et quia tunc illa nigredo non apparebit secundum esse suum proprium set secundum esse majoris, et ita quasi occultatur esse ejus proprium, licet major nigredo appareat." (Roger Bacon 1937: c. 24, 123.) He continues by pointing out that grey spots appear as black against a white background and as white against a black background. Their real color can only be seen when they are in a body that does not 
have any strong color. (ibid., 123-24). Note that Bacon considers this as a case in which two colors obscure each other, but in a special way.

${ }^{28}$ On the first aspect, see Lindberg 1976: 132-33; on the second and further references, see Silva 2017. This joint venture is made particularly clear by John Pecham, one of the most read medieval perspectivists, in his Perspectiva communis (Pecham 1970: I.56-7, 136-39).

${ }^{29}$ On Alhacen's theory of visual perception, see Sabra 1978: 160-185; Smith 2015.

${ }^{30}$ DA III.2.50.

${ }^{31}$ On this threefold level of perception, see Silva 2017. All references are to Mark Smith's edition and translation.

32 DA III.3.1.

${ }^{33}$ DA III.3.6.

${ }^{34}$ DA III.2.61.

${ }^{35}$ DA III.2.7, 566

${ }^{36}$ DA III.2.15.

${ }^{37}$ DA III.2.19, 261.

${ }^{38}$ DA III.2.21.

${ }^{39}$ DA III.7.25.

${ }^{40}$ DA III.7.22.

${ }^{41}$ DA III.2.62; see also DA III.5.7.

${ }^{42}$ For Alhacen, the perception of the size of an object is the result of collating distance and visual angle (see, e.g., DA III.7.16). Since the transmission of visual information continues beyond the eyes up to the ultimate sensor (ultimum sentiens, the name he uses for the perceptual capacity), one could suppose that this distance also counts for the overall distance between object and perceiver, but Alhacen denies that this is the case (DA III.7.25). The justification is that this internal pathway is not covered by the visual rays, and thus, cannot be measured. Distance in turn is perceived from the relative spatial disposition of bodies in the visual field (DA III.7.64).

${ }^{43}$ DA III.5.10.

${ }^{44}$ DA III.5.14.

${ }^{45}$ DA III.3.8; and DA III.4.5 \& III.5.4, respectively.

${ }^{46}$ DA III.3.9.

47 "Thus, when each of the conditions that have been listed falls within its proper range of moderation, the true form of the visible object will appear as it actually exists." DA III.3.34, 593.

${ }^{48}$ DA III.3.15.

${ }^{49}$ For a general overview of medieval theories of the internal senses, see Di Martino 2008; Toivanen 2013, 22545.

${ }^{50}$ E.g., when Thomas Aquinas discusses the possibility of comparing two perceptual qualities that belong to the same genus-e.g., white and black - to each other, he writes that: "Est etiam aliud considerandum, quod sensus et intellectus non solum recipiunt formas rerum, sed etiam habent iudicium de ipsis; iudicium autem de contrariis non est contrarium, sed unum et idem, quia per unum contrariorum sumitur iudicium de alio." (Thomas Aquinas 1985: 18, 99b217-222.)

51 “[...] hoc mobile esse nigrum et hoc rubicundum esse acidum." (Avicenna 1968: IV.1, 6.)

${ }^{52}$ See footnote 7 above.

53 "In compositione tamen sensibilium magna frequenter est deceptio, sicut quid est quod est coloratum, ut utrum croceum sit mel aut cholera citrina aut ubi est coloratum aut quid est, quod sonat, aut ubi sonat, et sic de aliis. Et causam huius infra dicemus esse quoniam sensus proprius non habet componere, sed aliqua superior potentia, et illius est error." (Albertus Magnus 1968: II.3.5, 103, emphasis added.)

54 "Est autem aliud sensibile, ut haec individua demonstrata sentire accidit sensui, quod vocamus sensibile per accidens, et in illo incidit mendacium in sensum, quia illud est per compositionem et divisionem sensibilis per se ad aliud quod non accipit sensus, et aliquando componitur vere, aliquando autem falso. Visus enim albi non mentitur, quod album sit; inquantum autem album dicit esse hoc vel illud per affirmationem vel negationem, saepe mentitur." (Albertus Magnus 1968: III.1.8, 175.) The example of a yellow substance that is perceived as being sweet/bitter comes from Aristotle (DA III.1, 425a30-b4; SE V, 167b4-5) and Avicenna (1968: IV.1, 7-8). For a recent analysis of Avicenna's position, see Kaukua 2014: 99-116.

55 "In visione autem corporali sepe fallitur anima, cum in ipsis corporibus fieri putat quod sit in corporeis sensibus: sicut navigantibus videntur moveri que stant in terra; et intuentibus celum sidera stare que moventur; et divariatis oculorum radiis, res una habere duas formas, ut unus homo habere duo capita, et in aqua remus fractus, et multa huiusmodi." (John of la Rochelle 1995: II.2.65, 193.)

${ }^{56}$ Sens. VII, 448b12-14; DA III.3, 428b2-4. Four cubits is about one foot (the size of a football). 
57 "[...] licet enim circa compositionem coloris cum subiecto vel divisionem ipsius ab ipso contingat error, tamen circa colorem numquam est error. Visus enim semper rubeum dicit esse rubeum, componere autem rubeum cum hoc subiecto quod est cuprum, vel cum hoc subiecto quod est aurum, non est visus, sed sensus communis, ut infra habebitur. Et circa illam compositionem et divisionem frequenter contingit mentiri; multi enim cuprum crediderunt esse aurum, et multi mel fel putaverunt, eo quod citrinum est utrumque." (Albertus Magnus 2008: 261, II. 8-18.)

58 "[...] quaecumque virtus comparat inter sensata plurium, oportet, quod accipiat sensata plurium; et hoc non potest facere aliquis sensus proprius. Et quia hoc non est proprium alicuius sensus particularis, ideo frequens fit deceptio circa hoc [...] quia saepe, cum accipit citrinum, hoc ipsum putat esse amarum, et ita mel aliquando opinatur esse fel." (Albertus Magnus 1968: II.4.6, 156.)

59 The conscious judgment, or perceptual belief in the robust sense, is not a perceptual judgment of the kind that medieval thinkers took common sense to be responsible for; rather, it is an intellectual judgment. Sometimes there can be a conflict between the two kinds of judgments. For instance, in the case of the famous Müller-Lyer illusion, we perceive one line as being longer than another, although we know that they are both equally long. It is extremely difficult to let our conscious judgment concerning the relative lengths of the lines affect the perceptual involuntary judgment, which is, according to medieval authors, made by the common sense.

${ }^{60}$ On Aristotle on bile, see Aristotle 2003: 288.

61 Non-human animals cannot form propositional thoughts, but they are capable of making these kinds of perceptual errors. See, e.g., Thomas Aquinas 1984: II.13, 121b-22b; Pasnau 2002: 271. A useful discussion and references can be found in Oelze 2018: 52-87.

62 "[...] trepidum decipitur in timore existens, et amans decipitur in amore vehementi existens, in tantum ut etiam propter modicam similitudinem videatur timenti quod videat hostes, et amanti videatur quod videat dilectum." (Albertus Magnus 1890: II.1.7, 167a.)

${ }^{63}$ According to medieval authors, emotions involve both cognitive and physiological aspects. For instance, anger is a desire for revenge or punishment, which is accompanied with boiling blood around the heart. This description originates in Aristotle (DA I.1, 403a25-b19), and it was commonly accepted in the Middle Ages. See e.g. Thomas Aquinas, ST II-1.22.2; 44.1; 37.4. On medieval theories of emotions, see Knuuttila 2004.

${ }^{64}$ Animal spirits were thought to be a special type of highly refined physical matter, which is prepared from blood and which moves in the three chambers of the brain and in the nerves. In medieval medical theory (which was also used by philosophers), it was the physiological carrier of psychological powers and functions (see Harvey 1975).

65 “[...] febricitantibus quibus materia vaporat ad caput, videtur quod animalia videant in parietibus propter modicam similitudinem linearum casu protractarum in parietibus: et quidem taliter infirmantium quibus non detinetur rationis usus, vehementer decertant apud se contra phantasmata, scientes esse falsum [...]. Si autem maior sit passio infirmitatis, in tantum quod detineat rationem, tunc movetur ab ipsa similitudine irascendo, vel timendo, vel concupiscendo, sicut re praesente." (Albertus Magnus 1890: II.1.7, 167a-b.)

${ }^{66}$ Albertus Magnus 1890: II.1.7, 167b.

${ }^{67}$ DA II.3.44.

68 DA III.6.2.

${ }^{69}$ DA III.6.4-5.

${ }^{70}$ DA III.6.6.

71 "Pari modo accidit error in arboribus triplex: in individuis, in communibus formis, in utrisque. Unde aliquando una amigdalus extimatur alia; aliquando a longitudine magna pirus magna apparet amigdalus; aliquando pirus Petri apparet amigdalus Martini." (DA III.6.6, 297, transl. 597.)

72 DA III.4.7.

73 DA III.7.2.

${ }^{74}$ DA II.7.13; DA III.6.10.

75 DA III.7.1.

${ }^{76}$ DA III.7.9; see also III.7.164-165.

77 DA III.7.193-194.

${ }^{78}$ Roger Bacon 1996: II.3.2, 206-7. For Bacon, who adopts the three-fold classification of visual perception, this case corresponds to an instance of perceptual recognition (i.e., perception by means of prior knowledge).

79 DA III.7.26.

${ }^{80}$ The object can move either at the same speed as you, in which case the distance remains the same and the object's apparent size does not change, or it may be moving faster than you, which means that it looks smaller and smaller. See DA III.7.32. 
${ }^{81}$ DA III.7.33.

${ }^{82}$ Lagerlund 2010.

${ }^{83}$ See e.g. Denery 2005; Perler 2014.

${ }^{84}$ Tachau 1988: 93-4. Auriol writes, e.g., that: "The act of the external sense puts the thing in intentional being" ("actus exterioris sensus ponit rem in esse intentionali") (Peter Auriol 1956: I.3.14, 696.)

${ }^{85}$ Friedman 2015: 141-50; Adriaenssen 2017b. Friedman makes a strong case that despite the obvious terminological differences between modern philosophical discussions concerning phenomenological consciousness and Auriol's medieval vocabulary involving the notion of esse apparens, the crucial philosophical idea is the same. Adriaenssen approaches the issue from the point of view of skepticism.

${ }^{86}$ Peter Auriol 2009: d. 35, q. 1.1, II. 320-321, 326-336.

${ }^{87}$ Peter Auriol 1956: I.3.14, 696-97. The two last examples appear in Cicero 1967: II.7.19, 492-93. Auriol also considers the case of mirror images, but we shall not examine this here-see Licka's contribution in this volume. 88 Perler 1994: 84.

89 "Cum igitur sensus exterior formativus sit, sic quod ponat res in esse intentionali, et similiter imaginatio idem habeat-nam pater meus imaginatus a me est, ipsemet positus in esse intentionali." (Peter Auriol 1956: I.3.14, 697-98.)

${ }^{90}$ Friedman 2015: 144; Adriaenssen 2017b: 82-7; Perler 1994. "[...] considerandum est quod res in esse formato posita non claudit in se aliquid absolutum nisi ipsam realitatem. Unde non ponit in numerum res et sua intentio quantum ad aliquid absolutum, claudit tamen aliquid respectivum, videlicet apparere. Quod non debet intelligi ut affixum aut superpositum illi rei, sicut ceterae relationes, sed omnino intrinsicum et indistinguibiliter adunatum." (Peter Auriol 2009: d. 27, q. 2, a. 2, II. 584-8. On the important distinction between the concerns with representationalism and apparent being, see Biard 2007.

91 "Tum quia in visu separantur, recipit enim quandoque videns ab obiecto qualitatem illam, quae non est aliud quam visio"; and "actio autem sensibilis et qualitas visibilis idem sunt." (Peter Auriol 2009: d. 35, q. 1, a. 1, II. 696-727.) See Tachau (1988, 92; 98).

${ }^{92}$ Friedman: 1997, 475.

${ }^{93}$ Friedman: 1997, 477. The notion of mental epistemic entities as having "diminished being" can be found in Roger Bacon 1983: I.1, 17, and later on Scotus, Ordinatio I, dist. 36, n.33.

${ }^{94}$ Peter Auriol 1956: 1.3.14, 698.

${ }^{95}$ Friedman 2015: 144.

${ }^{96}$ Friedman: 1997, 476. They have different modes of being not least because otherwise our knowledge would be limited to singular things. However, we do not have intellectual knowledge of a particular rose but of a universal one (rose simpliciter), and it is the universal which is put into apparent being by the intellect. Friedman 1997, 474. See also Friedman 1997, 432.

97 Perler 1994: 85.

${ }^{98}$ Peter Auriol 1952: prol. 2, 199-200. For a discussion, see Friedman 2015; Adriaenssen 2017a.

${ }^{99}$ To be sure, there is a clear phenomenological difference between perceiving and imagining, but Auriol's theory does not provide an explanation for this difference.

${ }^{100}$ Adriaenssen (2017a) argues that the criticism was not justified. By contrast, Tachau (1988) and Wood (1982) claim that it was. More skeptical approach to the success of Auriol's theory in warding off the skeptical worries is presented by Denery 2005: 135-36. 